\title{
Anti-inflammatory and antiproliferative activities of date palm pollen (Phoenix dactylifera) on experimentally-induced atypical prostatic hyperplasia in rats
}

Ahmed A Elberry ${ }^{1 *}$, Shagufta T Mufti ${ }^{2}$, Jaudah A Al-Maghrabi ${ }^{2}$, Essam A Abdel-Sattar ${ }^{3}$, Osama M Ashour ${ }^{4}$, Salah A Ghareib ${ }^{4}$ and Hisham A Mosli ${ }^{5}$

\begin{abstract}
Background: Atypical prostatic hyperplasia (APH) is a pseudoneoplastic lesion that can mimic prostate adenocarcinoma because of its cytologic and architectural features. Suspension of date palm pollen (DPP) is an herbal mixture that is widely used in folk medicine for male infertility. The aim of the present study was to evaluate the effect of DPP suspension and extract on APH-induced rats.

Methods: APH was induced in adult castrated Wistar rats by both s.c. injection of testosterone $(0.5 \mathrm{mg} / \mathrm{rat} /$ day $)$ and smearing citral on shaved skin once every 3 days for 30 days. Saw palmetto $(100 \mathrm{mg} / \mathrm{kg})$, DPP suspension (250, 500 and $1000 \mathrm{mg} / \mathrm{kg}$ ), and lyophilized DPP extract (150,300 and $600 \mathrm{mg} / \mathrm{kg}$ ) were given orally daily for 30 days. All medications were started 7 days after castration and along with testosterone and citral.

Results: The histopathological feature in APH-induced prostate rats showed evidence of hyperplasia and inflammation. Immunohistochemical examination revealed that the expressions of IL-6, IL-8, TNF- $\alpha$, IGF-1 and clusterin were increased, while the expression of TGF- $\beta 1$ was decreased that correlates with presence of inflammation. Moreover, histopathological examination revealed increased cellular proliferation and reduced apoptosis in ventral prostate. Both saw palmetto and DPP treatment has ameliorated these histopathological and immunohistochemical changes in APH-induced rats. These improvements were not associated with reduction in the prostatic weight that may be attributed to the persistence of edema.
\end{abstract}

Conclusion: DPP may have a potential protective effect in APH-induced Wistar rats through modulation of cytokine expression and/or upregulation of their autocrine/paracrine receptors.

Keywords: atypical prostatic hyperplasia, date palm pollen, anti-inflammatory, antiproliferative, cytokines, immunohistochemistry, castration, citral

\section{Introduction}

Benign prostatic hyperplasia (BPH) is a hormone- and age-related disease, characterized by histological changes and variable increases in prostatic size [1]. Atypical prostatic hyperplasia (APH) or adenosis is a pseudoneoplastic lesion that can mimic prostate adenocarcinoma because of its cytologic and architectural features. APH is

\footnotetext{
* Correspondence: berry_ahmed@yahoo.com

'Department of Clinical Pharmacy, Faculty of Pharmacy, King Abdulaziz University, Jeddah, Saudi Arabia

Full list of author information is available at the end of the article
}

usually an incidental finding in transurethral resections or simple prostatectomies performed in the clinical setting of BPH [2]. In these prostate diseases, there is an imbalance between prostate cell growth and apoptosis. This imbalance is complex and influenced by factors that stimulate proliferation and minimize cell apoptosis such as growth factors, cytokines and steroid hormones [3].

The role of inflammation in prostate diseases is suggested by the presence of inflammatory cells within the prostate in BPH patients [4]. The more the inflammation, the larger the prostate will be [5]. Inflammation is

\section{C) Biomed Central}


a complex phenomenon consisting of a humoral (cytokines) and cellular (leukocytes, monocytes and macrophages) components [3]. Inflammation is usually a selflimited event, with initial pro-inflammatory cytokines, growth factor release and angiogenesis followed by antiinflammatory cytokine-mediated resolution [6]. Chronic inflammation continuously produces inducible cyclooxygenase (COX-2) that increases the production of prostaglandin-E2 (PGE2) and reduces the E-c adherin protein [7]. Chronic inflammation also produces free radicals as various reactive oxygen species (ROS) [8].

Suspension of Phoenix dactylifera date palm pollen (DPP) is an herbal mixture that is widely used as a folk remedy for curing male infertility in traditional medicine [9]. A thousand tonnes of DPP are produced every year by millions of palm trees grown in the Arabian region. DPP differed from bee pollen in that it is of a known source and its homogeneity, purity and is easily to be standardized. DPP was reported to have gonadal stimulating potency [10], as well as fertility promotion in women in ancient Egypt [11]. It was reported that date pollen grain extracts contain estrogenic materials, estrone, as gonad-stimulating compounds that improve male infertility and exhibit gonadotrophin activity in the rat $[11,12]$. Cernilton is another pollen extract derived from several different plants in southern Sweden and has been known to be effective in the treatment of chronic abacterial prostatitis and prostatodynia $[13,14]$.

The aim of this study was to investigate the protective effect of DPP suspension and its alcoholic extract on the histpathological changes related to inflammation, proliferation and/or apoptosis in APH using citral and testosterone-induced $\mathrm{APH}$ model in castrated rats.

\section{Methods}

\section{Chemicals and reagents}

Antibodies against clusterin, phospho-Smad2, and $\beta$-actin were obtained from Santa Cruz Biotechnology (Santa Cruz, CA; anti-clusterin for Western blot analysis); Upstate Biotechnology [Lake Placid, NY; anti-clusterin for immunohistochemistry (IHC)]; and Cell Signaling Technology Inc. (Danvers, MA). Antibody against TGF- $\beta 1$ ligands were purchased from Dakocytomation (Carpinteria, CA). Citral was obtained from Fluka Chemie AG, Buchs, Switzerland. Testosterone was obtained from Sigma-Aldrich and Dakocytomation (Carpinteria, CA).

\section{Collection and extraction of date pollen sample}

Date palm pollen sample was collected from El-Katawiah, El-Sharkia, Egypt. It was collected in March 2010 and kept in $20^{\circ} \mathrm{C}$ till extraction. $1250 \mathrm{~g}$ DPP powder was extracted with $80 \%$ ethanol $(3 \times 5$ liters $)$ by using Ultraturrax T25 homogeniser (Janke and Kunkel, IKA Labortechnik, Stauten, Germany) at a temperature not exceeding $25^{\circ} \mathrm{C}$. The extract was evaporated under reduced pressure, lyophilized to give $240 \mathrm{~g}$ of yellowish semisolid residue and protected from light at $4{ }^{\circ} \mathrm{C}$ until use.

\section{Experimental animals}

Adolescent male Wistar rats, aged 50-60 days, were obtained from the animal facility of King Fahd Research Center, King Abdulaziz University, Jeddah, Saudi Arabia. They were used in the study according to the guidelines of the Biochemical and Research Ethics Committee at King Abdulaziz University, in accordance with the NIH guidelines. Animals were housed in a well-ventilated, temperature-controlled room at $22 \pm 3^{\circ} \mathrm{C}$ with a $12 \mathrm{~h}$ light-dark cycle. They were provided with standard rat chow pellets and tap water. All experimental procedures were performed between 8-10 a.m. and care was taken to avoid stressful conditions.

Orchidectomy was performed aseptically, under ethyl ether anesthesia, by a midscrotal incision. Following ligation of the spermatic cord and vessels, testes and epididymides were removed. The remaining stump was pushed back through the inguinal canal into the abdominal cavity, and the scrotal sac was closed by sutures [15]. After castration, the rats were maintained under standard laboratory conditions for 7 days in order to allow a definite involution of the prostatic gland [16].

APH was induced as previously described by Engelstein et al. [17] in castrated rats using citral and testosterone. Rats were subcutaneously injected with testosterone propionate in corn oil $(0.5 \mathrm{mg} / 0.1 \mathrm{ml} / \mathrm{rat})$ each day for 30 days. Citral, $1 \mathrm{M}$ diluted in 70\% ethanol, was smeared on a different shaved area of skin, each time, on the back at a final dose of $185 \mathrm{mg} / \mathrm{kg}$ every $4^{\text {th }}$ day for 30 days. Control groups were smeared with the solvent (ethanol) alone at the shaved skin. Considering the pungent lime fragrance of citral, the control groups were kept in a separate location from the citral-treated animals to avoid possible false results as citral have some influence via the olfactory tract [17].

\section{Animal treatment}

Seven days after castration, the animals were randomly divided into nine groups $(n=7)$. Group I served as shamed operation received corn oil $(0.1 \mathrm{ml} / \mathrm{rat})$ and $1 \%$ CMC-Na $(0.3 \mathrm{ml} / 100 \mathrm{~g}$ body $\mathrm{wt})$ daily during the period of the experiment. Groups from II-IX were castrated and had APH. Group II served as negative control and received $\mathrm{CMC}-\mathrm{Na} 1 \%$ as previously mentioned. Group III served as positive control and received saw palmetto $(100 \mathrm{mg} / \mathrm{kg})$. Groups from IV-VI were treated with DPP suspension (DPPS) at doses of 250,500 or $1000 \mathrm{mg} / \mathrm{kg} /$ day respectively by oral gavage. Groups from VII-IX were treated with 150,300 , or $600 \mathrm{mg} / \mathrm{kg} /$ day of DPP 
extract (DPPE) respectively. All the DPP powder and extract were suspended in $1 \% \mathrm{CMC}-\mathrm{Na}$ and were given to rats once daily by oral gavage along with testosterone injection and citral smearing for 30 days as described before by Scolnik et al. [18]. After scarifaction, ventral prostate of each rat in each group were removed from the body, $24 \mathrm{hr}$ after the last administration, and weighed. Half of the tissues were frozen in liquid nitrogen and stored at $-75^{\circ} \mathrm{C}$ until use. The remaining tissues were fixed immediately in $0.1 \mathrm{M}$ phosphate-buffered $10 \%$ formalin $(\mathrm{pH} 7.4$ ) for $48 \mathrm{~h}$ and then embedded in paraffin and were used for histological studies. Serial 4$\mu$ m-thick sections from each tissue specimen were prepared and mounted on poly-L-lysinecoated glass slides. These were used for detection of IL- 6 and TGF- $\beta 1$ receptors by immunohistochemistry.

\section{Histopathology and Histoscore}

A part of the ventral lobes were separated and fixed overnight in Stieve's solution. Thereafter, the tissue was thoroughly rinsed with water, and immersed overnight in ethanol $70 \%$. Then, it was dehydrated, embedded in paraffin, and $5 \mathrm{~mm}$ thick sections were cut and stained by Harris' hematoxylin eosin, according to standard procedures [19].

A score-chart protocol (histoscore) developed by Scolnik et al. [18] was used to obtain an objective quantitative assessment (Table 1). The examination, description, and scoring of the slides were performed in a blinded manner. The scoring system presented in arbitrary units to make a better evaluation. In a second step, the cumulative score in each group were correlated to the final histological diagnosis in order to establish a range score for normal and hyperplasia. Additional histological inflammatory score described by De Nunzio et al. [20] was used to evaluate the inflammation. Score 0: no inflammation, Score 1: scattered inflammatory cell infiltrate without nodules, score 2 : no confluent lymphoid, score 3: Large inflammatory areas with confluence.

\section{Immunohistochemistry and Immunhistoscoring}

Hematoxylin and eosin staining was performed to observe histopathology. For analysis of IL- 6 and TGF- $\beta 1$ expression, sections from the paraffin embedded tissue blocks were mounted on charged glass slides and baked at $60^{\circ} \mathrm{C}$ for $1 \mathrm{hr}$ in the oven, then mounted in Ventana staining machine. Dewaxed by EZ Prep (Xylene substitute) and rehydrated. The tissue sections were heated in Ventana buffer $\mathrm{CC} 1$ ( $\mathrm{pH}$ 6) to facilitate antigen retrieval, treated with $\mathrm{H}_{2} \mathrm{O}_{2}$ to eliminate endogenous peroxidase. This was followed by incubation for $60 \mathrm{~min}$ at room temperature with primary antibodies IL- 6 and TGF- $\beta 1$. The dilutions used were; IL-6 (dilution 1:50) and TGF- $\beta 1$ (dilution of 1:25). Subsequently, the sections were incubated with biotinylated secondary antibody using avidin-biotin complex method. The immunoreaction was visualized using diaminobenzidine. All sections were lightly counterstained with hematoxylin as a back ground. The positive controls used for IL- 6 and TGF$\beta R 1$ were from the colon. The negative controls comprised serial sections that were stained using equivalent concentrations of nonimmune mouse IgG in place of the primary antibodies. The level of staining was evaluated independently by three observers blinded to experimental conditions.

Expression of TGF- $\beta 1$ and IL- 6 was evaluated according to a semiquantitative scale: -0 , no detectable staining at all; 1 , less than $10 \%$ of the cells stained positive; 2,10 $-50 \%$ positive cells; and 3 , more than $50 \%$ of cells positive [21]. Staining intensity was scored as 0 (no detectable stain), 1 (weak staining detected at intermediate to high power), 2 (moderate detected at low to intermediate power) to 3 (strong detected at low power) [22].

\section{Reverse transcriptase-polymerase chain reaction (RT-PCR)}

Total RNA was extracted from the snap-frozen tissue samples using total RNA isolation kit (Macherey-Nagel) according to the manufacturer's instructions. RT was performed in a $10 \mu \mathrm{l}$ reaction mixture. The RT reaction contained $1 \mu \mathrm{g}$ RNA, $10 \mathrm{mM}$ Tris- $\mathrm{HCl}(\mathrm{pH} 8.3), 50 \mathrm{mM} \mathrm{KCl}$, $1.5 \mathrm{mM} \mathrm{MgCl} 2,2.5 \mathrm{mM}$ dithiothreitol, $500 \mu \mathrm{mol} /$ liter each of dATP, dCTP, dGTP, and dTTP, 40 U RNasin, 25 $\mu \mathrm{g} / \mathrm{ml}$ oligo $\mathrm{d}(\mathrm{T}) 12-18$, and 100UMoloney murine leukemia virus reverse transcriptase (Bioline, London, UK). The reaction mixture was incubated at $42^{\circ} \mathrm{C}$ for $60 \mathrm{~min}$ and then heated to $80^{\circ} \mathrm{C}$ for $5 \mathrm{~min}$. The resultant cDNA was used for PCR. For quantitative real-time RT-PCR, we prepared appropriate dilutions of each single-strand cDNA followed by normalizing of the cDNA content using $\beta$ actin as a quantitative control. Quantitative PCR amplification was performed with a $25-\mu \mathrm{l}$ final volume consisting of $1 \mu \mathrm{l} \mathrm{RT}$ reaction mixture, $3 \mathrm{mM} \mathrm{MgCl} 2,10 \mathrm{pmol}$ of each sense and antisense primer, and $12.5 \mu \mathrm{l}$ (Roche Diagnostics) (Table 2). PCR conditions were as follows: initial denaturation at $95^{\circ} \mathrm{C}$ for $10 \mathrm{~min}$ and 35 cycles of denaturation at $94^{\circ} \mathrm{C}$ for $1 \mathrm{~min}$, annealing at $55^{\circ} \mathrm{C}$ for $1 \mathrm{~min}$, and elongation at $72^{\circ} \mathrm{C}$ for $2 \mathrm{sec}$ with a final elongation at $72^{\circ} \mathrm{C}$ for $10 \mathrm{~min}$. samples were migrated in 1\% agarose gel using electrophoresis, UV visualized, and images were analyzed using totallab120 (Nonlinear Dynamic Ltd). Clusterin, TGF- $\beta 1$, IGF-1, IL-6, IL-8, and TNF- $\alpha$ expression in the test samples were normalized to the corresponding $\beta$-actin level and were reported as the relative band intensity to the $\beta$-actin gene expression.

\section{Statistical analysis}

Data were expressed as mean $\pm \mathrm{SE}$ and were analyzed by analysis of variance (ANOVA) followed by Tukey- 
Table 1 Cumulative chart score of histological findings (Arbitrary Units) in rat ventral prostate [19]

\begin{tabular}{|c|c|c|}
\hline Strain & Experimental group & Animal no. \\
\hline & & subtotal \\
\hline \multicolumn{3}{|c|}{ Low-Power Magnification } \\
\hline Luminal shape & regular (1); villous (3); papillary (4); cribriform (5) & -——- \\
\hline Acinar shape & tubular (1); branched (3); irregular (5) & \\
\hline Interacinar shape & large or moderate (1); back-to-back glands (5) & -—— \\
\hline Stroma & fine (1); abundant (3); fibrosis/severe smooth muscle hyperplasia (5) & -—— \\
\hline \multicolumn{3}{|c|}{ High-Power Magnification } \\
\hline Epithelial shape: & flattened (1); cuboidal (1); cylindrical (3); hexagonal (5) & \\
\hline Number of layers: & $\begin{array}{l}\text { mono- (1); oligo, 2-4 (3); pluri, }>5 \text { (5) } \\
\text { If }>1 \text {, then add: focal (3); diffuse (5) }\end{array}$ & -——- \\
\hline Alignment: & $\begin{array}{l}\text { Polar (1); apolar (3) } \\
\text { If there is piling up of epithelial cells add (3) } \\
\text { If there is budding out of epithelial cells into stroma add (5) } \\
\text { If periacinar clusters of epithelial cells are found add (3) } \\
\text { If isolated clusters of epithelial cells are found outside acini add (5) }\end{array}$ & 一一一 \\
\hline Lesion distribution & $\begin{array}{l}\text { Unilobar: isolated (2); multiple (6) } \\
\text { Bilobar: isolated (4); multiple (8) }\end{array}$ & -—— \\
\hline \multicolumn{3}{|c|}{$\begin{array}{l}\text { Round, regular (1); irregular (5) } \\
\text { Small (2), large (2), small and large in the same acinus (4) }\end{array}$} \\
\hline Mitoses per field: & abundant, 3-5 (5); excessive, > 5 (10) & -——- \\
\hline Basement membrane: & $\begin{array}{c}\text { Intact (1); interrupted (5) } \\
\text { Thin (1); thick (5) }\end{array}$ & - - - \\
\hline \multicolumn{3}{|c|}{ Total score (arbitrary units) } \\
\hline
\end{tabular}

Other Findings: edema; congestion; hemorrhages; pyknotic nuclei-epithelial/stromal; mononuclear exudate-stromal/intraluminal

Kramer multiple comparisons test. Inflammation scores and their significance were calculated by Chi-square test with Yate's corrections. Differences were considered significant with a $P$ value less than 0.05 . Statistical analyses were performed using the SPSS for Windows (v. 10.0).

\section{Results}

\section{Changes in relative prostate weight}

Prostatic weights were increased significantly in APHinduced rats. There were no significant changes in relative prostate weight after treatment with either, saw palmetto, DPPS or DPPE (Table 3).

\section{Changes in gene expression of IL- 6 , IL-8 and TNF- $\alpha$}

Induction of $\mathrm{APH}$ in rats significantly increased the gene expression of proinflammatory cytokines; IL-6, IL-8 and TNF- $\alpha$. Saw palmetto treatment exerted a significant reduction in their levels compared to $\mathrm{APH}$-induced rat values. DPPE induced a similar effect to that of saw palmetto in a dose dependent manner. On the other hand, despite DPPS in a dose of $250 \mathrm{mg} / \mathrm{kg}$ increased the gene expression IL-6, IL- 8 and TNF- $\alpha$, it induced a dosedependent reduction of these genes at doses of 500 and $1000 \mathrm{mg} / \mathrm{kg}$ (Figure 1).

\section{Changes in gene expression of TGF- $\beta 1$, IGF-1 and} clusterin

Induction of prostatic hyperplasia in our model is accompanied with significant increase of the clusterin and IGF1 expression in ventral lobe of rat prostate, while the TGF- $\beta 1$ expression was significantly decreased. Saw palmetto treated rats with APH showed significant increase in clustrin and TGF- $\beta 1$ expression with a decrease in IGF-1 expression. All the treatment groups showed

Table 2 Primer for quantitative reverse transcriptase-polymerase chain reaction (RT-PCR) analysis

\begin{tabular}{|c|c|c|}
\hline Gene & Forward primer & Reverse primer \\
\hline$\beta$-actin & 5'-GTCACCCACACTGTGCCCATCT-3' & 5'-ACAGAGTACTTGCGCTCAGGAG-3' \\
\hline IL-6 & 5'-GAACTCCTTCTCCACAAGCG-3' & 5'-TाTCTGCCAGTGCCTCПT-3' \\
\hline $\mid \mathrm{L}-8$ & 5'-CTGCGCCAACACAGAAATTA-3' & 5'-ATTGCATCTGGCAACCCTAC-3' \\
\hline $\mathrm{TNF} \alpha$ & 5'-CAGAGGGAAGAGTTCCCCAG-3' & 5'-CCTTGGTCTGGTAGGAGACG-3' \\
\hline TGF-b & 5'-GTTCTTCAATACGTCAGACATTCG-3' & 5'-CATTATCTTTGCTGTCACAAGAGC-3' \\
\hline $\mid \mathrm{GF}-1$ & 5'-CACAGGCTATGGCTCCAGCAT-3’ & 5'-TCTCCAGCCTCCTCAGATCACA-3' \\
\hline Clusterin & 5'-CTGACCCAGCAGTACAACGA-3' & 5'-TGACACGAGAGGGGACTTCT-3' \\
\hline
\end{tabular}


Table 3 Body weight (BW), absolute prostate weight (APW), and relative prostate weight (RPW) of rats treated with date palm pollen suspension (DPPS) and the alcoholic extract (DPPE)

\begin{tabular}{ccccc}
\hline Treatment group & \multicolumn{2}{c}{ BW (gm) } & ABW (gm) & RBW (gm) \\
& start & end & & $0.452 \pm 0.051$ \\
Normal rats & $199.14 \pm 5.16$ & $229 \pm 8.810$ & $0.106 \pm 0.011$ & $2.721^{*} \pm 0.197$ \\
Rats with APH (negative control) & $187.6 \pm 8.656$ & $241.4 \pm 12.55$ & $0.656 \pm 0.056$ & $2.919^{*} \pm 0.217$ \\
Saw Palmetto (100 mg/kg) & $192.8 \pm 4.591$ & $258.3 \pm 10.22$ & $0.742 \pm 0.036$ & $3.15^{*} \pm 0.215$ \\
DPPS (250 mg/kg) & $190 \pm 5.024$ & $243.6 \pm 11.89$ & $0.752 \pm 0.025$ & $3.38^{*} \pm 0.274$ \\
DPPS (500 mg/kg) & $178.3 \pm 4.207$ & $221.8 \pm 7.127$ & $0.745 \pm 0.051$ & $2.79^{*} \pm 0.342$ \\
DPPS (1000 mg/kg) & $193.7 \pm 8.929$ & $275 \pm 11.547$ & $0.75 \pm 0.084$ & $2.92^{*} \pm 0.193$ \\
DPPE (150 mg/kg) & $215 \pm 7.693$ & $244.5 \pm 8.675$ & $0.719 \pm 0.044$ & $3.039^{*} \pm 0.343$ \\
DPPE (300 mg/kg) & $189.7 \pm 7.136$ & $232.9 \pm 9.425$ & $0.696 \pm 0.056$ & $3.10^{*} \pm 0.197$ \\
DPPE (600 mg/kg) & $184 \pm 5.219$ & $244.8 \pm 9.502$ & $0.752 \pm 0.036$ &
\end{tabular}

( $n=7$ rats in each group).

*Significantly different from normal rats at $\mathrm{p}<0.05$

significant increase in clustrin and TGF- $\beta 1$ expression accompanied with decreasing of IGF-1 expression in a dose dependent fashion (Figure 2).

\section{Histological changes}

Ventral prostates from the control normal group showed normal histological pattern with regular acini and average histoscore of $23.3 \pm 1.09$ units (Table 4). Ventral prostates from the APH-induced rats showed an increased irregular acinar growth and distribution. The acini were placed back to back with vilous projections. The lining epithelium was tall columnar with abundant eosinophilic cytoplasm. Nuclei were round, regular and basally placed in most acini. Epithelial pilling with focal loss of polarity and budding into surrounding stroma was seen in some prostatic sections. The basement membrane was thin and continuous. Isolated mitotic figures were seen in the range of 1-2/section examined. The interstitial stroma was scant and showed congested blood vessels with chronic inflammatory cells mainly lymphocytes and perivascular. These findings were associated with significant increase in the histoscore (Table 4 and Figure 3).

These pathological changes and histoscore were ameliorated in animals in the saw palmetto group (Table 4 and Figure 4). However, irregular and back to back acini, with focal pilling of epithelium, were persistent in isolated and multiple foci within the prostatic sections. These acini were lined by tall columnar epithelium and showed round, regular basally placed nuclei. No loss of polarity or budding into surrounding stroma was seen. Isolated mitotic figures in the range of 1-2/section were seen. The interstitial stroma was scant and showed vascular congestion. Rare chronic inflammatory cells were seen.

Similarly, DPPS $(250,500,1000 \mathrm{mg} / \mathrm{kg})$ and DPPE $(150,300,600 \mathrm{mg} / \mathrm{kg})$ ameliorated both the pathological features and histoscore of APH (Table 4 and Figure 4). However, persistent hyperplastic changes were seen with an uneven distribution. Most of the affected acini were dilated with intraluminal secretions. Few acini showed focal loss of lining epithelium although the basement membrane was still intact. Mitotic figures were absent in most cases and surrounding stroma showed edema. Occasional mixed acute and chronic inflammatory cells were seen along with few mast cells. Regarding the inflammatory score, treatment with saw palmetto, DPPS and DPPE showed significant inhibition of inflammation nearly in a non-dose dependent manner (Table 4).

\section{Immunohistochemistry}

Normal control rats showed no expression of all the three immunohistochemical markers. In the prostatic sections from APH-induced rats, TGF- $\beta 1$ expression score was 3 and showed strong intensity in the secretory epithelial cells of acini with focal strong expression in basal cells as well. IL- 6 expression score was 1 and showed weak intensity in the secretory epithelial cells only. No expression was observed in secretory, basal or stromal cells (Figure 5).

In saw palmetto treated APH-induced rats, TGF- $\beta 1$ expression score was 3 and showed strong intensity in the secretory epithelial cells of acini with focal strong expression in basal cells as well. IL-6 was variable between score 2-3 with a staining intensity between moderate to strong. No expression was observed in secretory, basal or stromal cells.

In DPPS $(250 \mathrm{mg} / \mathrm{kg})$ treated rats, TGF- $\beta$ R 1 expression score was 2 and showed moderate intensity in the secretory epithelial cells of acini with focal moderate expression in basal and stromal cells as well. IL-6 expression score was 2 with a strong staining intensity. No expression was observed in secretory, basal or stromal cells (Figures 6 and 7). 

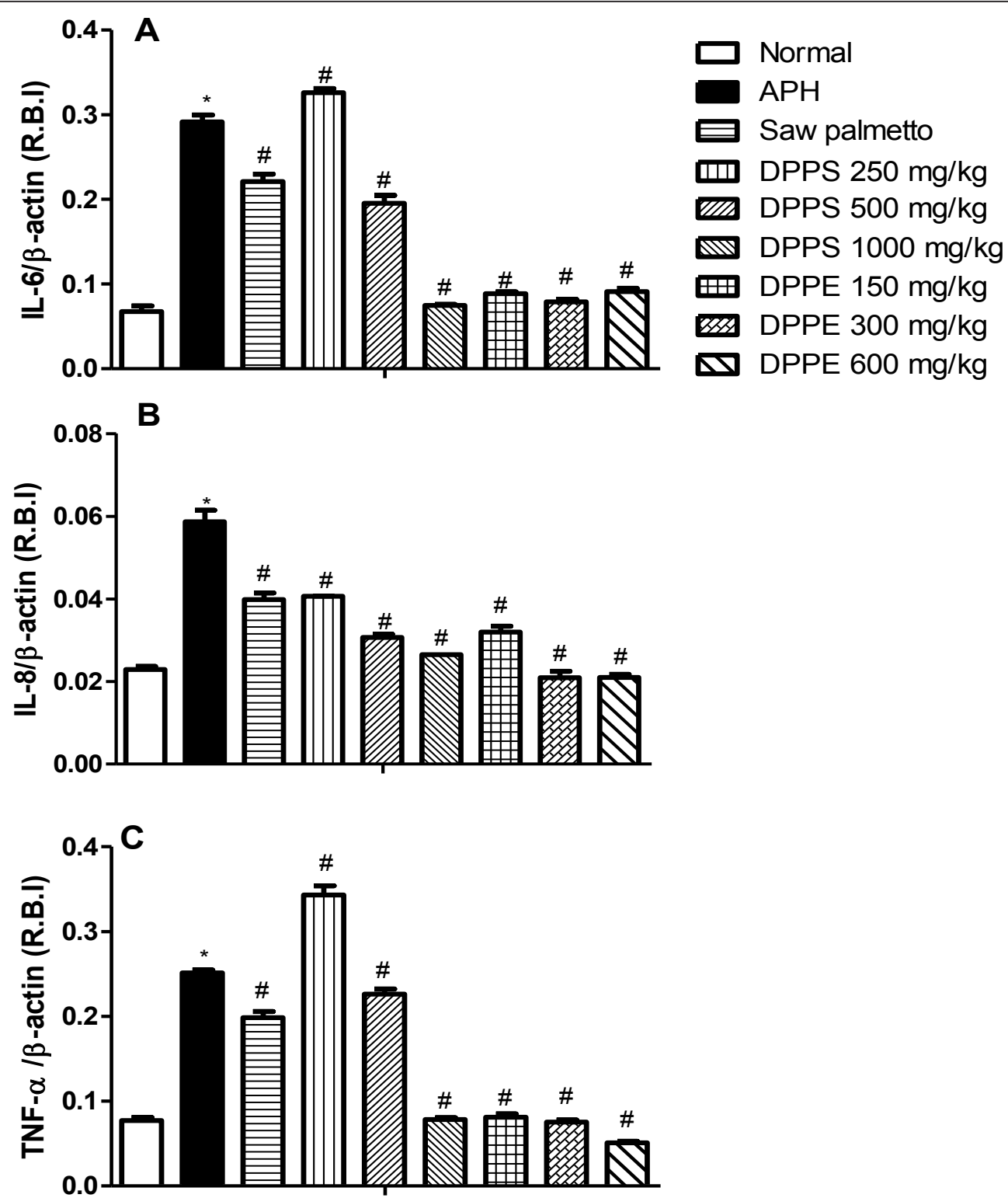

Figure 1 The expression of IL-6, IL-8 and TNF- $\alpha$ target genes in ventral prostate of Wistar rats after treatment with DPPS and DPPE. All values are expressed as mean \pm S.E. of the relative band intensity (R.B.I.) using $\beta$-actin as a reference. *Significantly different from normal control rats at $P<0.05$. \# Significantly different from $A P H$ control rats received $C M C$ at $P<0.05$.

In DPPS $(500 \mathrm{mg} / \mathrm{kg}$ and $1000 \mathrm{mg} / \mathrm{kg})$ treated rats, TGF- $\beta 1$ expression was score 3 and showed strong intensity in the secretory, basal epithelial cells of acini and stromal cells. IL-6 expression score was 3 with a strong staining intensity in secretory and stromal cells. The basal cells also showed focal strong expression of IL-6 with score 3. No expression was observed in secretory, basal or stromal cells. Although the immunoscore enhanced with increase in dose of DPPS from $250 \mathrm{mg} /$ $\mathrm{kg}$ to $500 \mathrm{mg} / \mathrm{kg}$, but no statistically significant dose related correlation was observed between a dose of 500 $\mathrm{mg} / \mathrm{kg}$ and $1000 \mathrm{mg} / \mathrm{kg}$.
In prostatic sections examined from the DPPE (150 $\mathrm{mg} / \mathrm{kg}$ ) treated rats, TGF- $\beta 1$ expression was variable between score 2-3 and showed moderate to strong intensity in the secretory and basal epithelial cells of acini and stromal cells. IL-6 expression was score 3 with a strong staining intensity in secretory and stromal cells. The basal cells showed focal strong expression with score 3. No expression was observed in secretory, basal or stromal cells

In DPPE $(300 \mathrm{mg} / \mathrm{kg}$ and $600 \mathrm{mg} / \mathrm{kg})$ treated rats, TGF- $\beta 1$ expression score was 3 and showed strong intensity in the secretory and basal epithelial cells of 

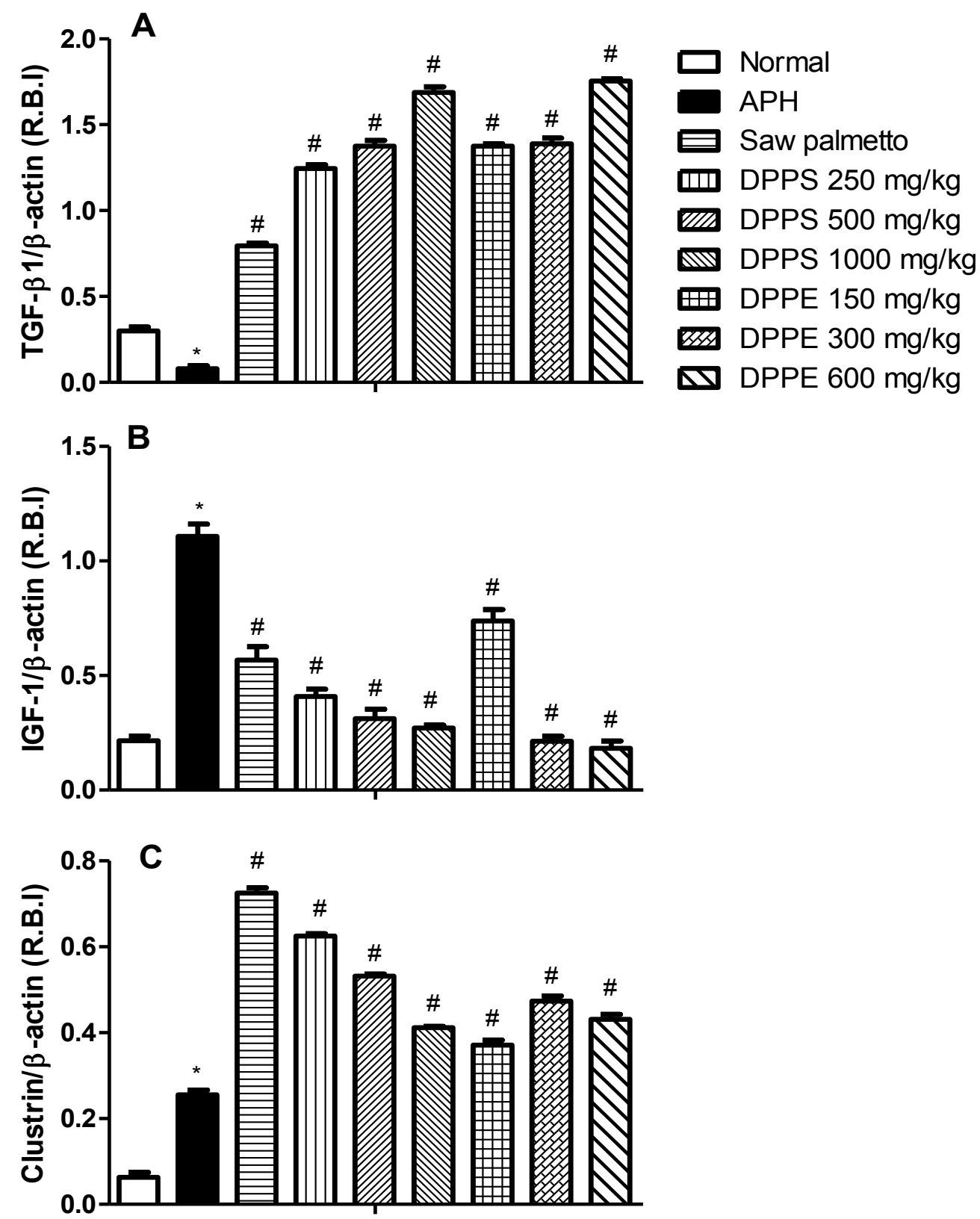

Figure 2 The expression of TGF- $\beta 1$, IGF-1 and Clusterin target genes in ventral prostate of Wistar rats after treatment with DPPS and DPPE. All values are expressed as mean \pm S.E. of the relative band intensity (R.B.I.) using $\beta$-actin as a reference. *Significantly different from normal rats at $P<0.05$. \# Significantly different from APH control rats received $C M C$ at $P<0.05$.

acini and stromal cells. IL-6 expression was score 3 with a moderate to strong staining intensity in secretory and stromal cells. The basal cells showed focal strong expression with score 3. No expression was observed in secretory, basal or stromal cells. Although the immunoscore enhanced with increase in dose of DPPE from 150 $\mathrm{mg} / \mathrm{kg}$ to $300 \mathrm{mg} / \mathrm{kg}$, but no statistically significant dose related correlation was observed between a dose of 300 $\mathrm{mg} / \mathrm{kg}$ and $600 \mathrm{mg} / \mathrm{kg}$ (Figures 6 and 7).

\section{Discussion}

The fact that APH arises always in prostates with concomitant BPH and exhibits several cancer like features, places $\mathrm{APH}$ as an intermediate lesion between $\mathrm{BPH}$ and the subset of well-differentiated prostatic cancers according to Bostwick et al. [23]. The pathogenesis of prostatic hyperplasia still remains largely unresolved, but a number of partially overlapping and complementary theories have been proposed. In the current study, 
Table 4 Histoscore and inflammatory scores in normal rats, atypical prostatic hyperplasia (APH)-induced rats and APHinduced treated treated with date palm pollen suspension (DPPS) and the alcoholic extract (DPPE) ( $n=7$ rats in each group)

\begin{tabular}{|c|c|c|c|c|c|}
\hline Treatment group & Histoscore & $\begin{array}{l}\text { Inflamm-atory } \\
\text { score }\end{array}$ & $\begin{array}{l}\text { Number of cases of inflammati- } \\
\text { on/tested rats }\end{array}$ & $\begin{array}{l}\text { Percentage } \\
\text { inflammation }\end{array}$ & $\begin{array}{l}\text { Percentage inhibition of } \\
\text { inflammation }\end{array}$ \\
\hline Normal rats & $23.30 \pm 1.09$ & 0 & 0 & - & - \\
\hline $\begin{array}{l}\text { Rats with APH } \\
\text { (negative control) }\end{array}$ & $40.14^{*} \pm 1.97$ & 1 & 7 & $100^{*}$ & 0 \\
\hline $\begin{array}{l}\text { Saw Palmetto }(100 \\
\mathrm{mg} / \mathrm{kg})\end{array}$ & $35.28^{*} \pm 2.37$ & 1 & 1 & $14.28^{*}$ & $85.72^{\#}$ \\
\hline DPPS (250 mg/kg) & $36.00^{*} \pm 2.21$ & 1 & 1 & $14.28^{*}$ & $85.72^{\#}$ \\
\hline DPPS (500 mg/kg) & $34.20^{*} \pm 2.75$ & 1 & 1 & $14.28^{*}$ & $85.72^{\#}$ \\
\hline DPPS (1000 mg/kg) & $34.70^{*} \pm 1.58$ & 1 & 0 & 0 & $100^{\#}$ \\
\hline DPPE (150 mg/kg) & $36.40^{*} \pm 2.51$ & 1 & 1 & $14.28^{*}$ & $85.72^{\#}$ \\
\hline DPPE (300 mg/kg) & $34.20^{*} \pm 1.96$ & 1 & 1 & $14.28^{*}$ & $85.72^{\#}$ \\
\hline DPPE $(600 \mathrm{mg} / \mathrm{kg})$ & $34.70^{*} \pm 1.97$ & 1 & 1 & $14.28^{*}$ & $85.72^{\#}$ \\
\hline
\end{tabular}

*Significantly different from normal control rats at $p<0.05$

\# Significantly different from APH control rats received CMC at $p<0.05$

Score 0: No inflammation

Score 1: Scattered inflammatory cells without nodules

Score 2: No confluent lymphoid aggregates

Score 3: Large areas of confluence

APH-induced rats revealed prostatic enlargement as a consequence of progressive acinar hyperplasia that confirmed the influence of androgen on prostate growth. These findings are in agreement with that of Abramovici et al. [24]. The development of hyperplasia was associated with enhanced proliferation and suppressed apoptosis of prostatic cells. The APH-induced rats showed an increase in both absolute and relative weights of ventral prostate lobe. This effect was accompanied by histopathological changes confirming the APH which was in agreement with that of Abramovici et al. [24] and Engelstein et al. [17]. It was suggested that APH induced in adult rats by citral may be attributed to its estrogeniclike effect through its binding nonspecifically to estrogen

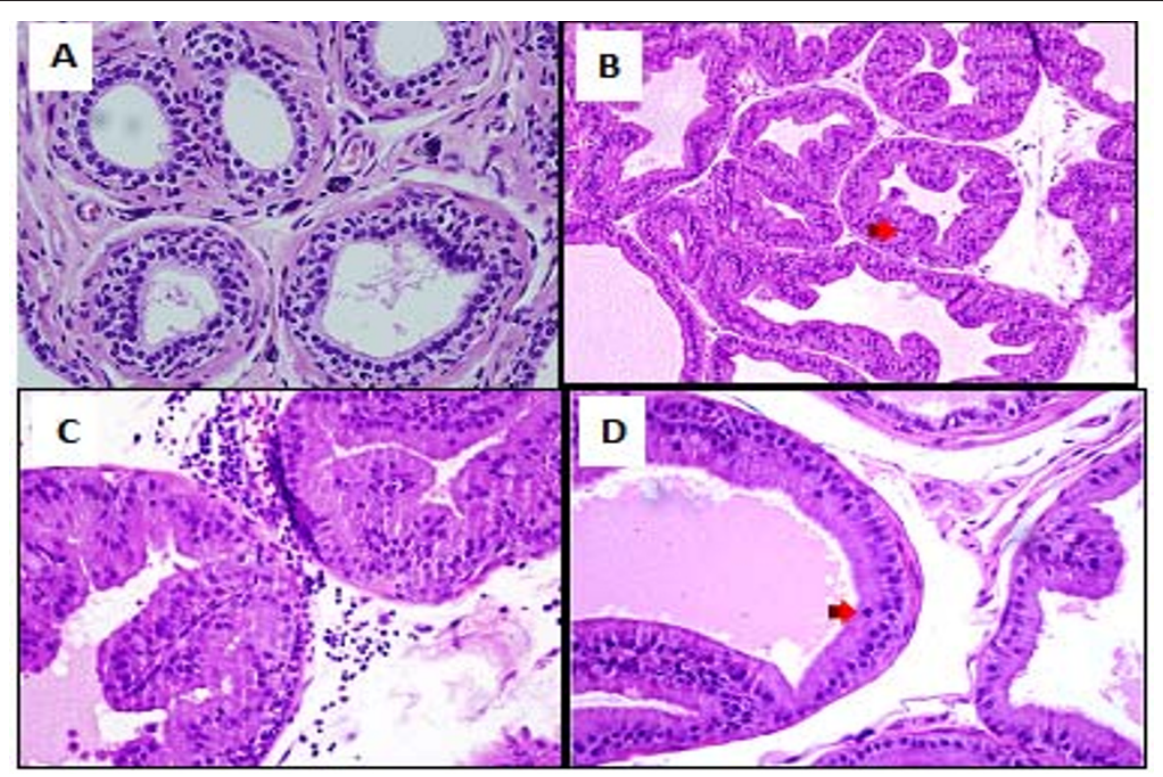

Figure 3 Prostate of normal rats with round regular acini with an intact basement membranes, the acinar lumina contain eiosinophilic and homogeneous secretions (A), citral and testosterone treated castrated rats with atypical prostatic hyperplasia (APH) showed an irregular acinar growth and distribution, the acini were increased in number, lined by tall columnar epithelium, crowded, irregular in outline and placed back to back with vilous projections (B), the intersititial stroma was scant and showed congested blood vessels with chronic inflammatory cells mainly perivascular lymphocytes (C) hyperplastic acini showing mitosis (D). 


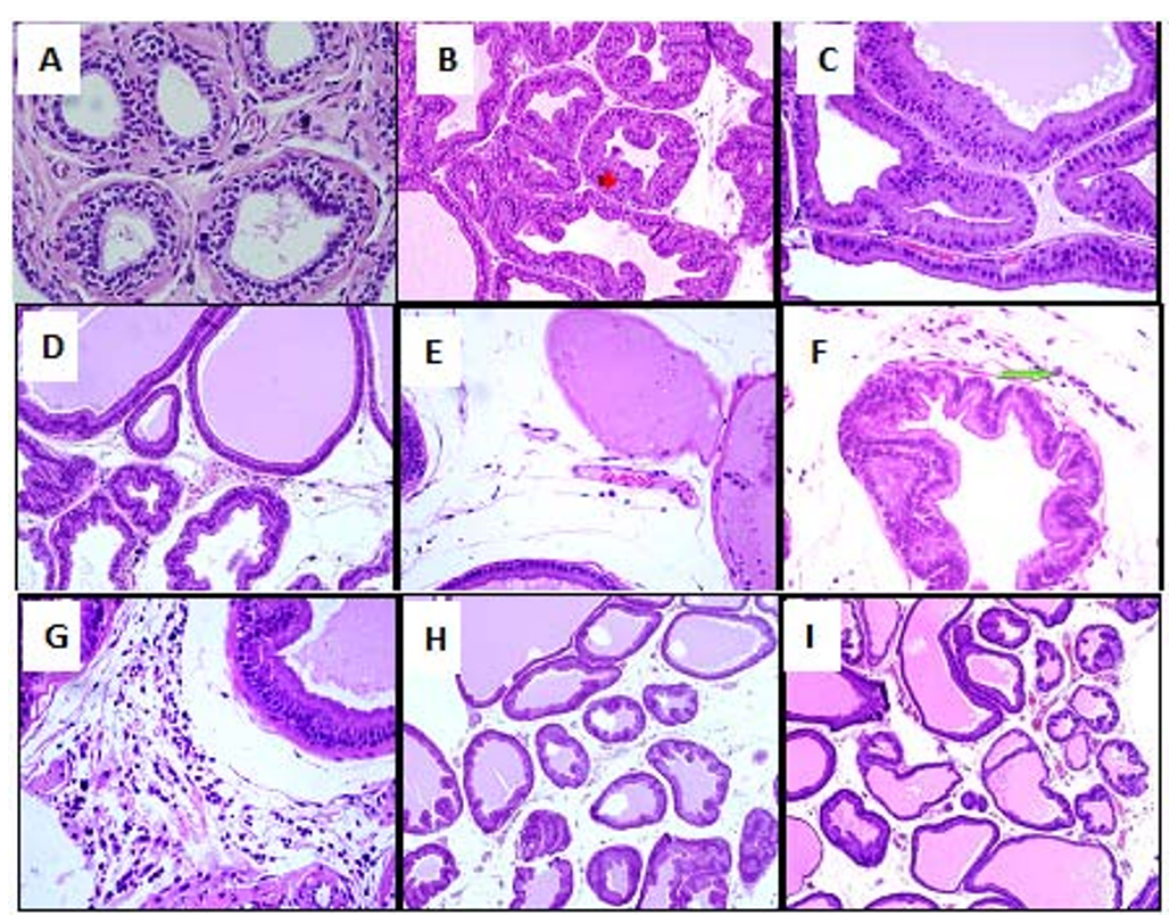

Figure 4 Normal rats ventral prostate (A), APH in the ventral rat prostate (B), Saw palmetto treated rats prostate showed a persistent hyperplastic acini that were lined by tall columnar epithelium with villous projections and rare chronic inflammatory cells in the stroma (C), DPP suspension (DPPS) showing decreased number of hyperplastic acini in the overall distribution of the lesion (D), hyperplastic acini showing focal loss of lining epithelium (E) few mast cells in the surrounding stroma along with edema (F) and occasional mixed acute and chronic inflammatory cells were seen (G). The prostate of the DPPE treated rats, showed a decrease in the number of acini in the overall distribution of the lesion $(H)$ and dilated acini with intraluminal secretions, mitotic figures and chronic inflammatory cells were absent in most cases and surrounding stroma was edematous (I).

receptors [25] located on prostate epithelial cells of both human [26] and rat [27]. Ho, et al. [27] also found that induction of type 2 estrogen-binding site in rat ventral prostate could be responsible for the proliferative response.
The hyperplastic changes induced in ventral prostate of rats in the current model were accompanied with an increased gene expression of IGF-1, IL-6, IL-8, TNF- $\alpha$ and decreased TGF- $\beta 1$. TGF- $\beta 1$ is the only known growth factor that can suppress tissue proliferation and induce cell

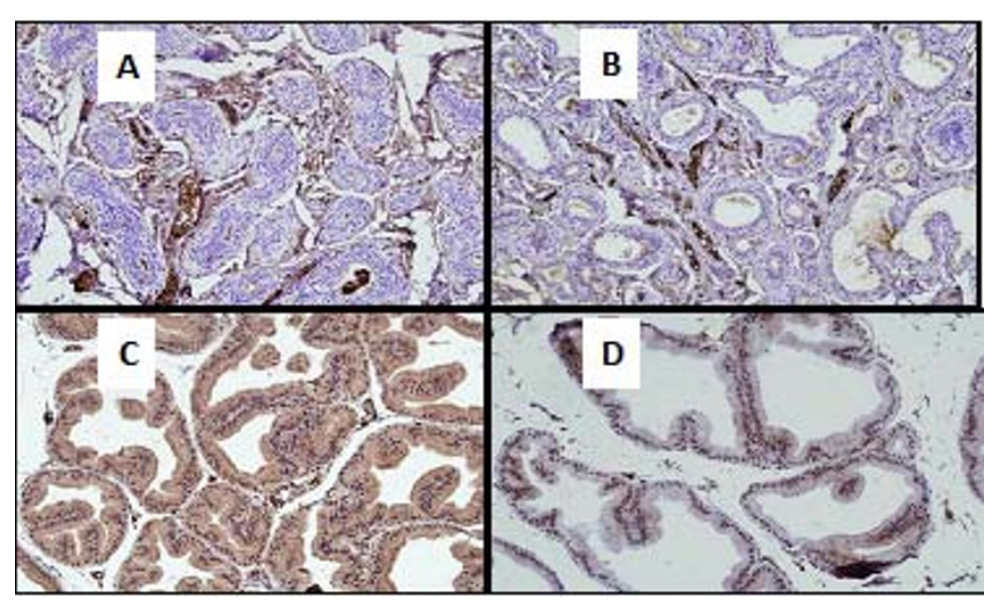

Figure 5 Immunohistochemical identification and quantification of TGF- $\beta$ I and IL- 6 of: Normal rat prostate TGF- $\beta$ I score 0 (A), Normal rat prostate IL-6 score 0 (B) APH control rat prostate TGF- $\beta$ I score 3 (C) and APH control rat prostate IL-6 score 1 (D). 


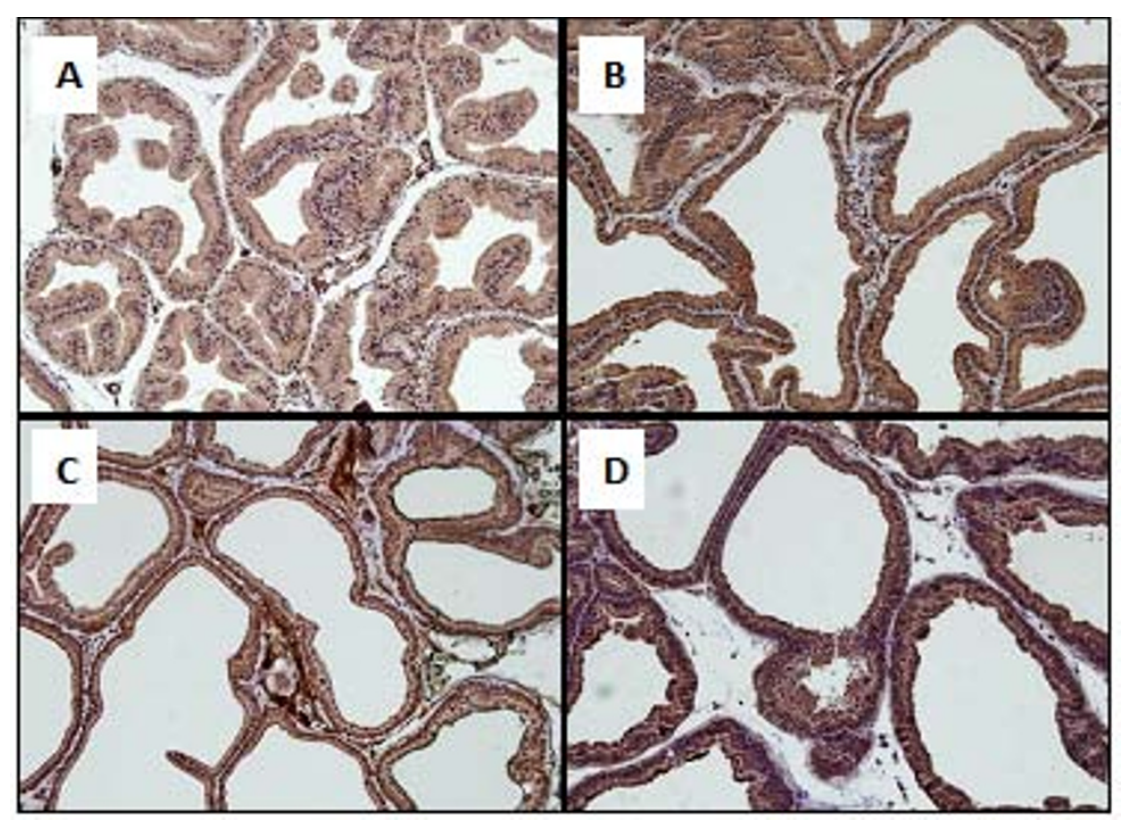

Figure 6 Immunohistochemical identification and quantification of TGF- $\beta R$, in APH control rat prostate score 2-3 (A), APH rat prostate treated with Saw Palmetto $100 \mathrm{mg}$ kg score 3 (B), APH rat prostate treated with DPPS (1000 $\mathrm{mg} \mathrm{kg}) \mathrm{score} 3(\mathrm{C})$ and APH rat prostate treated with DPPE $(600 \mathrm{mg} \mathrm{kg})$ score 3 (D).

apoptosis [28]. Circulating testosterone acts locally in the prostate via the production of growth factors such as IGF and TGF families that act in an autocrine or paracrine manner to influence prostate cell growth, survival, or apoptosis [29]. There are essentially two major classes of growth factors that are complimentary due to their effects on cell growth, namely growth stimulatory or mitogenic factors such as IGFs and growth inhibitory factors, including TGF- $\beta 1$. The prostate enlargement and the increased net weight of the ventral lobe may be partly due to, the increased IGF- 1 and decreased TGF- $\beta 1$ expression. This modulation in expression of these cytokines may play a

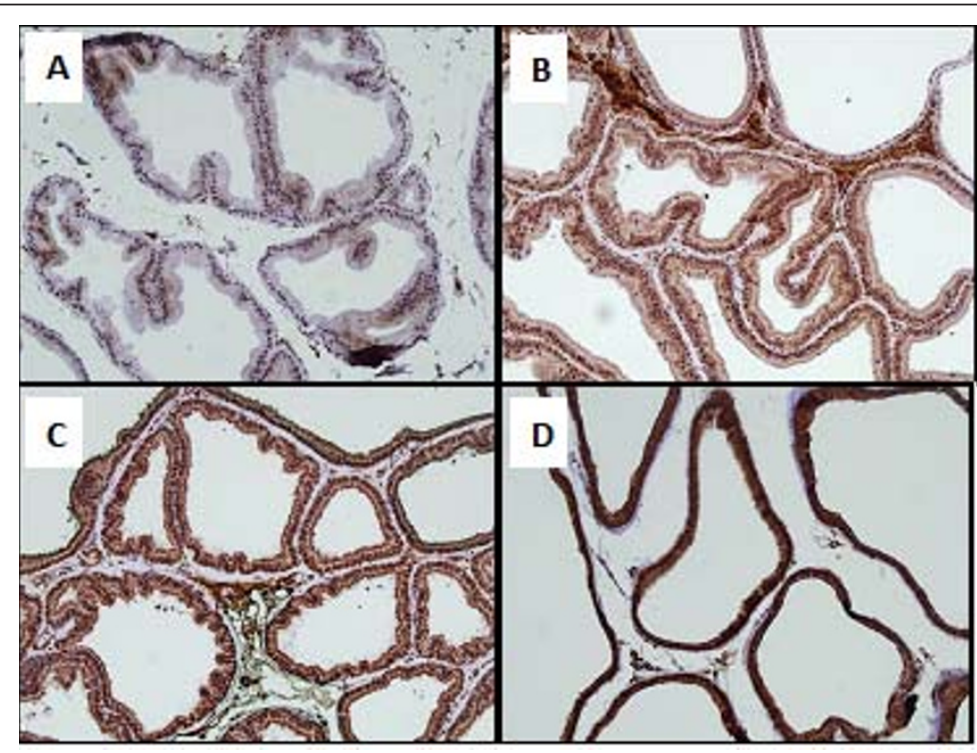

Figure 7 Immunohistochemical identification and quantification of IL-6 in; APH control rat prostate score 1 (A), APH rat prostate treated with Saw Palmetto $(100 \mathrm{mg} / \mathrm{kg})$ score $2-3(B)$, APH rat prostate treated with DPPS $(1000 \mathrm{mg} / \mathrm{kg}) \mathrm{score} 3$ (C) and APH rat prostate treated with DPPE $(600 \mathrm{mg} / \mathrm{kg})$ score $3(D)$. 
crucial role in prostate cell proliferation and apoptosis. These finding are in agreement with that of Wu et al. [30]. IGF-1, a mitogen, interacts with IGF-1 receptor stimulating cell proliferation [31] and inducing proliferative prostatic diseases [32].

Inflammation may play a role in prostatic hyperplasia [33]. About $40 \%$ of patients with $\mathrm{BPH}$ and $\mathrm{APH}$ exhibit chronic inflammatory features including infiltration by activated T cells, mast cells and macrophages [34]. Results of the present study showed that the enlargement of the ventral prostate of rats may be in part due to inflammation and over-expression of the pro-inflammatory cytokines including IL-6, IL- 8 and TNF- $\alpha$. It was reported that the infiltrated cells are capable of secreting growth factors and proinflammatory cytokines such as IL-6, IL-8, TGF- $\beta 1$ and IFN- $\alpha$ [33]. IL-6 is also secreted by both normal and prostatic epithelial cells and acts as a growth factor for normal prostatic epithelial cells [35]. IL-8 has chemotactic properties, attracting neutrophils and mononuclear cells into the sites of inflammation. It is a primary inflammatory cytokine, secreted by monocytes, mitogen-stimulated T lymphocytes, and many other prostatic cells [36]. IL-8 mRNA expression was upregulated as much as 5 -fold in peripheral blood lymphocytes of patients with prostatic carcinoma and in prostate tissues with hyperplasia and can act as a paracrine inducer of some potent growth factors for prostatic stromal cells [37]. TNF- $\alpha$, a pro-inflammatory cytokine, may induce inflammation by induction of COX-2, superoxide and hydrogen peroxide in human and rat mesangial cells [38]. TGF- $\beta$, an inflammatory cytokine, has been shown to regulate stromal proliferation and differentiation in $\mathrm{BPH}$, and it is a key factor for androgen control of prostatic growth. Recently, Descazeaud et al [39] investigated the TGF- $\beta$ receptor II protein (TGFBRII) expression in $231 \mathrm{BPH}$ patients using large-scale tissue microarrays analysis. They observed a significant association between TGFBRII stromal staining and prostatic volume.

Results of the present study showed that administration of DPPS and DPPE has ameliorated the histopathological changes and pro-inflammatory cytokine expression in APH-induced rats in a dose dependent manner as well as the inflammatory score in a non-dose dependent manner. These findings are in agreement with that of Ito et al. [40]. They reported that cernilton, the water soluble fraction of pollens extract of different plants, produced histological evidence of epithelial cell atrophy and significant reduction in the size of ventral and dorsal lobes of prostate in mature Wistar rats. These effects may be due to the anti-inflammatory activity of the DPP. In the context of chronic inflammation and expression of proinflammatory cytokines, IL-6 is one of the major physiologic mediators of acute phase reaction that influence immune responses and inflammatory reactions [36].

Pollen extract contains five different phytosterols and a biological active peptide that can influence the intracellular metabolism in biological systems [13]. Pollen extract showed a decrease in the leucocyte number in the prostatic expressate in $59 \%$ of all cases [13]. The water-soluble fraction attenuated the inflammatory response in experimental animals [41]. The in vitro experiments suggested that GBX (an acetone-soluble cernitin pollen extract) could be either a smooth muscle relaxant or a potent cyclo-oxygenase and lipoxygenase inhibitor [14]. The selectivity of pollen extract for the prostate was also supported by the work carried out by Ito et al. [40]. The homogenous effect of pollen-extract on the bladder outflow obstruction, showed higher values of urine volume voided and reduced flow time in both prostatitis and $\mathrm{BPH}$ [13]. The anti-inflammatory and decongestive effects of pollen-extract, give the evidence for the therapeutic benefit in patients with nonbacterial prostatitis or prostodynia $[13,42]$. The significant decrease in the A-P diameter of the prostate in patients treated with cernilton suggests that the prostate size was reduced. Nakase et al. [43] reported that T-60 (a water-soluble cernitin pollen extract) and GBX inhibited the contraction of muscle induced by noradrenaline, with evidence for competitive antagonism of noradrenalin at the site of adrenergic receptors. The subjective improvement in symptoms of nocturia and bladder emptying could be due to the effect of pollen extract on the rich adrenergic innervation of the bladder neck and prostate [44]. Similar findings were recorded in the present study in APH-induced rats treated with saw palmetto. Saw plametto was reported to inhibit growth factors-induced cell proliferation [45]. It has been reported that the liposterolic extract of Saw palmetto has antiandrogenic effects, [46] and inhibits the type 1 and type 2 isoenzymes of 5-alpha-reductase [47].

The reduction in the number of acini and the absence of mitotic figures in the surrounding stroma during treatment with both DPPS and DPPE may be due to increased tissue apoptosis and decreased proliferation. Results of the present study showed that DPP increased the expression of TGF- $\beta$ I and clusterin while decreased the expression of IGF-1 in rat ventral lobe prostate. Overexpression of TGF- $\beta 1$ and clusterin showed the increased rate of apoptosis of acini on the ventral prostate.

\section{Conclusion}

The findings of the present study clearly suggest that suspension or extract of DPP has ameliorating effect on the prostatic hypertrophy and inflammation. DDP treatment reduced the number of prostatic acini in $\mathrm{APH}$ rat 
model and decreased the production of pro-inflammatory cytokines. Prostatic tissues proliferation was decreased and apoptosis was increased during the treatment with DPP suspension and extract. The watery edema found during DDP treatment was responsible for the increased volume and hence the weight of the ventral lobe. This may explain the non-significant change of ventral prostate weight after treatment despite of the anti-inflammatory, antiproliferative and apoptotic effects. Further studies may be required for longer time treatment to study the effects of DPP on the absolute and relative weight of ventral lobe as well as the total net weight of the prostate in this model of APH in rats.

\section{Acknowledgements}

This work was supported by Sheikh Ahmed H. Fetaihi, Chair for Research on Prostatic Diseases, King Abdulaziz University, Jeddah, Saudi Arabia. We would like also to thank Mr. Islam Farouk, Department of Pharmacology and Toxicology, Faculty of Pharmacy, King Abdulaziz University, Jeddah, Saudi Arabia for his great effort and help in the experimental study.

\section{Author details}

'Department of Clinical Pharmacy, Faculty of Pharmacy, King Abdulaziz University, Jeddah, Saudi Arabia. ${ }^{2}$ Department of Pathology, Faculty of Medicine, King Abdulaziz University, Jeddah, Saudi Arabia. ${ }^{3}$ Department of Pharmacognosy, Faculty of Pharmacy, Cairo University, Cairo, Egypt. ${ }^{4}$ Department of Pharmacology and Toxicology, Faculty of Pharmacy, King Abdulaziz University, Jeddah, Saudi Arabia. ${ }^{5}$ Department of Urology, Faculty of Medicine, King Abdulaziz University, Jeddah, Saudi Arabia.

\section{Authors' contributions}

SG and HM designed the study. AE, OA and SG executed the experiments in the manuscripts. EA was responsible for collection and extraction of date pollen. SM and JA were involved in histopathological and immunohistochemical study as well as data analysis and manuscript preparation. All authors read and approved the final manuscript.

\section{Competing interests}

The authors declare that they have no competing interests.

Received: 30 October 2011 Accepted: 23 December 2011 Published: 23 December 2011

\section{References}

1. Kim J, Yanagihara Y, Kikugawa T, Ji M, Tanji N, Masayoshi Y, Freeman MR: A signaling network in phenylephrine-induced benign prostatic hyperplasia. Endocrinology 2009, 150:3576-3583.

2. Helpap B: The biological significance of atypical hyperplasia of the prostate. Virchows Arch A Pathol Anat Histol 1980, 387:307-317.

3. Sciarra A, Mariotti G, Salciccia S, Gomez AA, Monti S, Toscano V, Di Silverio F: Prostate growth and inflammation. I Steroid Biochem Mol Biol 2008, 108:254-260.

4. Novara G, Galfano A, Berto RB, Ficarra V, Navarrete RV, Artibani W: Inflammation, apoptosis, and BPH: What is the evidence? Eur Urol Suppl 2006, 5:401-409.

5. Wang L, Yang J, Yang L, Liu Z: Chronic inflammation in benign prostatic hyperplasia: Implications for therapy. Medical Hypotheses 2008, 70:1021-1023.

6. Sandhu JS: Prostate cancer and chronic prostatitis. Current Urol Reports 2008, 9:328-332.

7. Fernandez F, de Beer PM, van der Merwe L, Heyns CF: COX-2 promoter polymorphisms and the association with prostate cancer risk in South African men. Carcinogenesis 2008, 29:2347-2350.

8. Rigas $B$, Sun $Y$ : Induction of oxidative stress as a mechanism of action of chemopreventive agents against cancer. Br J Cancer 2008, 98:1157-1160.
9. Bahmanpour S, Talaei T, Vojdani Z, Panjehshahin MR, Poostpasand A, Zareei S, Ghaeminia M: Effect of Phoenix Dactylifera Pollen on Sperm Parameters and Reproductive system of Adult Male Rats. Iran J Med Sci 2006, 31:208-212.

10. Soliman FA, Soliman A: The gonad stimulating potency of date palm pollen grains. Experientia 1958, 14:92-93.

11. Bajpayee KK: Ethnobotany of Phoenix (Arecaceae). JETB 1997, 21:155-157.

12. Dostal LA, Faber CK, Zandee J: Sperm motion parameters in vas deferens and cauda epididymal rat sperm. Reprod Toxicol 1996, 10:231-235.

13. Ebeling $L$ : Therapeutic results of defined pollen extract in patients with chronic prostatitis or BPH accompanied by chronic prostatitis. In Therapy of prostatitis. Edited by: Schmiedt E, Alken JE, Bauer H W. Zuckschwerdt Verlag, Milnchen; 1986:154-160.

14. Buck AC, Rees RWM, Ebeling L: Treatment of chronic prostatitis and prostatodynia with pollen extract. Br J Urol 1989, 64:496-499.

15. Golomb E, Kruglikova A, Dvir D, Parnes N, Abramovici A: Induction of Atypical Prostatic Hyperplasia in Rats by Sympathomimetic Stimulation. Prostate 1998, 34:214-221.

16. Sandford NL, Searle JW, Kerr JF: Successive waves of apoptosis in the rat prostate after repeated withdrawal of testosterone stimulation. Pathol 1984, 16:406-410.

17. Engelstein D, Shmueli J, Bruhis S, Servadio C, Abramovici A: Citral and testosterone interaction in inducing benign and atypical prostatic hyperplasia in rats. Comp Biochem Physiol 1996, 115:169-177.

18. Scolnik MD, Servadio C, Abramovici A: Comparative Study of Experimentally Induced Benign and Atypical Hyperplasia in the Ventral Prostate of Different Rat Strains. J Androl 1994, 15:287-297.

19. Lillie RD: "Histopathologic Techniques and Practical Histochemistry". McGraw-Hill, New York; 1965.

20. De Nunzio C, Kramer G, Marberger M, Montironi R, Nelson W, Schröder F, Sciarra A, Tubaro A: The controversial relationship between benign prostatic hyperplasia and prostate cancer: the role of inflammation. Eur Urol 2011, 60:106-1017.

21. Hobisch A, Rogatsch H, Hittmair A, Fuchs D, Bartsch G Jr, Bartsch G, Culig Z: Immunohistochemical localization of interleukin-6 and its receptor in benign, premalignant and malignant prostate tissue. J Pathol 2000, 191:239-244.

22. Gounder SK, Chang VT, Hoover D, Gonzalez ML, Ahmed S, Finch-Cruz C, Duque L, Zhong F, Toomey K, Kasimis BS: Prostate cancer immunohistochemical (IHC) stains and survival in stage D3 patients (pts). J Clin Oncol 2008, 26:22187.

23. Bostwick DG, Cooner WH, Denis L, Jones GW, Scardino PT, Murphy GP: The association of benign prostatic hyperplasia and cancer of the prostate. Cancer 1992, 70:291-301.

24. Abramovici A, Servadio C, Shmuely J, Sandbank U: Experimental induction of atypical hyperplasia in rat ventral prostate. In Prostate Cancer. Part A: Research. Endocrine Treatment and Histopathology. Edited by: Murphy GP, Khoun S. Alan R Liss, New York; 1987:559-568.

25. Geldof AA, Enel C, Rao BR: Estrogenic action of commonly used fragrant agent citral induces prostatic hyperplasia. Urol Res 1992, 20:139-144.

26. Brolin J, Skoog L, Ekman P: Immunohistochemistry and biochemistry in detection of androgen, progesterone and estrogen receptors in benign and malignant human prostatic tissue. Prostate 1992, 20:281-295.

27. Hoe S, Leav I, Merk FB, Yu M, Kwan PW, Ziar J: Induction of atypical hyperplasia, apoptosis, and type II estrogen-binding sites in the ventral prostate of noble rats treated with testosterone and pharmacologic doses of estradiol-17 $\beta$. Lab Invest 1995, 73:356-365.

28. Soulitzis N, Karyotis I, Delakas D, Spandidos DA: Expression analysis of peptide growth factors VEGF, FGF2, TGFB1, EGF and IGF1 in prostate cancer and benign prostatic hyperplasia. Int J Oncol 2006, 29:305-314.

29. Marinese D, Patel R, Walden PD: Mechanistic Investigation of the Adrenergic Induction Of Ventral Prostate Hyperplasia in Mice. Prostate 2003, 54:230-237.

30. Wu S, Sun H, Qi X, Tu Z: Effect of Epristeride on the Expression of IGF-1 and TGF-beta Receptors in Androgen-Induced Castrated Rat Prostate. Exp Biol Med 2001, 226:954-960

31. Furlanetto RW, Dicarlo JN, Wisehart C: The type II insulin-like growth factor receptor does not mediate deoxyribonucleic synthesis in human fibroblasts. J Clin Endocrinol Metab 1987, 64:1142-1149. 
32. Culig Z, Hobisch A, Cronauer MV, Radmayr C, Hittmair A, Zhang J, Thurnher M, Bartsch G, Klocke H: Regulation of prostatic growth and function by peptide growth factors. Prostate 1996, 28:392-405.

33. Kramer G, Marberger M: Could inflammation be a key component in the progression of benign prostatic hyperplasia? Curr Opin Urol 2006, 16:25-29.

34. Sciarra A, Di Silverio F, Salciccia S, Autran Gomez AM, Gentilucci A, Gentile V: Inflammation and chronic prostatic diseases: evidence for a link? Eur Urol 2007, 52:964-972.

35. Giri D, Ozen M, Ittmann M: Interleukin-6 is an autocrine growth factor in human prostate cancer. Am J Path 2001, 159:2159-2165.

36. Djavan B, Eckersberger E, Espinosa G, Kramer G, Handisurya A, Lee C, Marberger M, Lepor H, Steiner GE: Complex Mechanisms in Prostatic Inflammatory Response. Eur Urol Supp/ 2009, 8:872-878.

37. Veltri RW, Miller MC, Zhao G, Ng A, Marley GM, Wright GL Jr, Vessella RL, Ralph D: Interleukin-8 serum levels in patients with benign prostatic hyperplasia and prostate cancer. Urology 1999, 53:139-47.

38. Radeke HH, Meier B, Topley N, Floge J, Habermehl GG, Resch K: Interleukin 1a and tumor necrosis factor-a induce oxygen radical production in mesangial cells. J Clin Invest 1990, 37:767-775.

39. Descazeaud A, Weinbreck N, Robert G, Vacherot F, Abbou CC, Labrousse F, Allory Y, Rubin MA, de la Taille A: Transforming growth factor betareceptor II protein expression in benign prostatic hyperplasia is associated with prostate volume and inflammation. BJU Int 2011, 108(2Pt 2):E23-E28.

40. Ito R, Ishii A, Yamashita S: Cemitin pollenextract (Cernilton) Antiprostatic hypertrophic action of Cernitin pollen-extract (Cernilton). Pharmacometrics (Jpn.) 1986, 31:1-11.

41. Kimura M, Kimura I, Nakase K: Micturition activity of pollen extract: contractile effects on bladder and inhibitory effects on urethral smooth muscle of mouse and pig. Planta Med 1986, 2:148-151.

42. Osborn DE, George NJR, Rao PN: Prostatodynia-physiological characteristics and rational management with muscle relaxants. Brit $J$ Urol 1981, 53:621-623.

43. Nakase K, Takenaga K, Hamanaka T, Kimura M: Inhibitory effect and synergism of cernitin pollen extract on the urethral smooth muscle and diaphragm of the rat. Nippon Yakurigaku Zasshi 1988, 91:385-392.

44. Buck AC, Cox R, Rees RW, Ebeling L, John A: Treatment of outflow tract obstruction due to benign prostatic hyperplasia with the pollen extract, Cernilton. A double-blind, placebo controlled study. Br J Urol 1990, 66:398-404.

45. Vacher P, Prevarskaya N, Skryma R, Audy MC, Vacher AM, Odessa MF, Dufy B: The lipidosterolic extract from Serenoa repens interferes with prolactin receptor signal transduction. J Biomed Sci 1995, 2:357-365.

46. Ravenna L, Di Silverio F, Russo MA, Salvatori L, Morgante E, Morrone S, Cardillo MR, Russo A, Frati L, Gulino A, Petrangeli E: Effects of the lipidosterolic extract of Serenoa repens (Permixon) on human prostatic cell lines. Prostate 1996, 29:219-230.

47. Bayne CW, Grant ES, Chapman K: Characterization of a new coculture model for BPH which expresses 5-alpha-reductase types I and II: the effects of Permixon on DHT formation (abstract 70). Fourth International Consultation on BPH, Paris; 1997, 70.

doi:10.1186/1476-9255-8-40

Cite this article as: Elberry et al: Anti-inflammatory and antiproliferative activities of date palm pollen (Phoenix dactylifera) on experimentallyinduced atypical prostatic hyperplasia in rats. Journal of Inflammation 2011 8:40.

\section{Submit your next manuscript to BioMed Central and take full advantage of:}

- Convenient online submission

- Thorough peer review

- No space constraints or color figure charges

- Immediate publication on acceptance

- Inclusion in PubMed, CAS, Scopus and Google Scholar

- Research which is freely available for redistribution 